\title{
Discouragement Amongst Ageing Workers in Malta within an EU Context
}

\author{
Maria Brown and Michael Briguglio \\ University of Malta
}

Received 17 September 2008; accepted 5 October 2008

\begin{abstract}
This paper investigates perceptions of unemployed ageing workers in Malta, in relation to disadvantages in the labour market and to discouragement with regard to chances of finding stable employment. The principal results are that educational level and number of breadwinners in one's household significantly affect perceptions; and that there are cases manifesting the 'discouraged worker effect', even though they are still registering to find employment. This challenges traditional views arguing that this effect is present only among individuals who already gave up the job search completely. This paper concludes that the struggle for productive employment requires mass representation of trade unions, which, in turn, require the construction of alliances to widen their appeal.
\end{abstract}

\section{Keywords}

ageing workers, discouragement, Malta, European Union

\section{Introduction}

This paper explores the perceptions related to chances of finding stable employment of the unemployed aged 40 years and over in Malta participating in an employment scheme - the Training and Employment Exposure Scheme (TEES). This scheme was funded by the European Union (EU) and the Government of Malta. It was specifically designed for this particular age-cohort of registered unemployed workers in Malta and was implemented between 2004 and 2006.

The global decline in employability of older workers during the last few decades has been described as "one of the most remarkable labour market 
transformations in modern times." ${ }^{1}$ Economic activity rates among older people, and especially older men, are still below that of the workforce as a whole. ${ }^{2}$ According to the European Commission, the unemployment rate is particularly high for older workers in Europe. ${ }^{3}$

In Malta unemployment amongst ageing workers is relatively high. The National Action Plan (NAP) for Employment, Malta 2004 identifies the older workforce as one of the main targeted groups needing more integration in stable employment. ${ }^{4}$ This paper analyzes whether ageing workers in Malta feel disadvantaged in the labour market, and whether negative perceptions lead to discouragement, particularly when it comes chances of finding stable employment.

The analysis is based on a quantitative empirical study consisting of a questionnaire administered to a representative sample of TEES participants. ${ }^{5}$ Statistical testing was carried out in order to establish correlations between the socio-demographic data of respondents and their perceptions on the scheme and their status in the labour market as ageing workers. The next sections of this paper shall discuss theoretical concepts related to the issue at stake.

\section{Post-Fordism and Knowledge-based Society}

In Post-Fordist contexts, "workers, instead of acquiring a skill for life, can now look forward to at least one if not multiple bouts of deskilling and reskilling in a lifetime." ${ }^{\circ}$ Moreover, the globalization of economic production, together with the spread of information technology, is, in many instances altering the nature of employment. ${ }^{7}$ A new type of economy - "a knowledge and service economy" - has emerged in various societies such as EU member states, whereby most workers are employed in knowledge or service-based jobs. ${ }^{8}$ In such an economy ideas, information, and forms of knowledge underpin innovation and economic growth. Changing pat-

\footnotetext{
1) Duncan 2003, p.101.

2) Loretto, Vickerstaff, and White, 2005.

3) European Commission 2004a, p.29.

4) Ministry of Education (Malta) 2004, p.4.

5) Brown 2007.

6) Harvey 1990, p.230.

7) Giddens 1998.

8) Giddens 2007, p.22.
} 
terns of economic inequality have come about, whereby low skill level is an important factor that characterizes job precariousness. ${ }^{9}$ Ageing workers whose skills do not match those demanded in the labour market can therefore be victims of such inequality. Their skills can no longer be marketable, and their trades may have been lost to countries offering cheaper labour. They can therefore take the role of a reserve army of labour in the Marxian sense. ${ }^{10}$ In this regard, it is pertinent to note that the Presidency Conclusions of the Lisbon European Council call for "Europe's education and training systems... to adapt both to the demands of the knowledge society and to the need for an improved level and quality of employment." ${ }^{11}$

\section{Ageism}

For the purposes of this paper, reference is made to ageism directed to older workers. Ageing workers may also be victims of hegemonic ideological manoeuvers in the form of ageism. ${ }^{12}$ (Formosa, 2000) Evidence of this can take place through employers' attitudes and practices towards older workers. ${ }^{13}$ Thus, older employees are dismissed without justification; they are forced to retire on a non-contractual basis; and face maximum age limitations for initial employment, promotions, and training, with little or no basis of justification.

\section{Social Capital}

Social capital, which can be explained in terms of social networks can also explain the difficulties faced by ageing workers. It has been argued that occupation is one of the social inequalities that persists in society and that determines the degree of social capital, which in turn influences socio-economic status of the individual. ${ }^{14}$ Thus, unemployment breaks down social networks hence depleting the social capital of the individual. As a result, finding employment is further hindered as a result of lack of social capital.

\footnotetext{
9) Giddens 2007, p.74.

10) Marx 1971.

11) EUROPA 2000.

12) Formosa 2000.

13) Platman and Tinker 1998, pp.513-535.

14) Alcock and Erskine 2003.
} 
In simple words, unemployment results in the loss of contacts that are needed to get back into employment.

\section{Discouragement}

In this paper discouragement shall be related to Katherine S. Newman's identification of any slip in occupational status, loss of income, place in society, social status or prestige. ${ }^{15}$ This is a broader perspective than, for example that of van Ham, Mulder and Hooimeijer. ${ }^{16}$ who relate discouragement to workers who would officially given up the job-search completely. Hence, in the context of Newman's definition of discouragement, falling into unemployment fits in this scenario. Factors affecting downward mobility range from market fluctuation, to public policy, merging, and post-industrialization scenarios. ${ }^{17}$

\section{Family Factors}

It can be argued that for ageing workers who have economically dependent family members - such as housewives, especially in view of Malta's low female participation rate in the labour market $-34.9 \%$, the lowest in the $\mathrm{EU}^{18}$ - or children, downward mobility and unemployment are more problematic and discouraging. Here one should note that most children in Malta keep living with parents till full adult age. ${ }^{19}$ Ageing persons may also be responsible for the care of the elderly, particularly if ill or disabled, even though such care-work also depends on other variables such as class and gender. ${ }^{20}$ Caring of elderly relatives is common amongst Maltese families, within the context of a welfare system that is heavily influenced by Catholic values. ${ }^{21}$

\footnotetext{
15) Newman 1988, p.23.

16) van Ham, Van Ham, Mulder and Hooimeijer 2001, p.10.

17) Newman 1988, p.30.

18) Eurostat 2008, p.253.

19) Rizzo 2004, pp.16-17.

20) Cheal 2002, pp.94-95.

21) Tabone 1995, pp.43-44; Rizzo 2004, p.18.
} 


\section{Unemployed Ageing Workers as a Distinct Non-Homogeneous Social Group}

Notwithstanding that ageing workers are a distinct social group within the working class, a sociological analysis should take account of "subaltern segments" 22 - namely sub-divisions within the same group in terms of gender, ethnicity, and so forth. In this regard, Formosa distinguishes between certain ageist policies that affect the lives of the elderly irrespective of class, social status, race, and gender, and other policies that affect subaltern segments or cohorts of older persons in a much more negative manner. ${ }^{23}$

\section{Unemployment in Malta}

Malta's unemployment rate, $7.3 \%$ is lower that the EU average of $8.2 \%{ }^{24}$ However, Malta's employment rate stands at $54.8 \%,{ }^{25}$ and only $30 \%$ of older workers in Malta are in gainful employment, ${ }^{26}$ which are very low percentages compared to most other EU member states. Only Poland has lower participation rates in both cases. ${ }^{27}$ In Malta, the unemployment rate among older workers ( 45 years of age and over) currently stands at $3.8 \%$, and such workers comprise around $35 \%$ of all those in the unemployment register. ${ }^{28}$ In this regard, the European Commission states that "the employment rate in Malta is particularly low compared to EU15 average. The employment rate of older workers is particularly low." ${ }^{29}$ Recommendations from the Commission in this regard include:

- Increasing adaptability of workers and enterprises;

- Attracting more people to the labour market and making work a real option for all;

- Investing more effectively in human capital and lifelong learning. ${ }^{30}$

\footnotetext{
22) Formosa 2000.

23) Formosa 2000.

24) Eurostat 2008, p.260.

25) Eurostat 2008, p.250.

26) Eurostat 2008, p.253.

27) Eurostat 2008, p.250, p.253.

28) National Statistics Office (Malta), 2008.

29) European Commission 2004a, p.29.

30) European Commission 2004b, pp.29-30.
} 
Malta's Employment and Training Corporation (ETC) has introduced various schemes to help registered unemployed workers find employment. ${ }^{31}$ (ETC, 2004a) Of particular interest for this paper is the TEES scheme, from which respondents of the empirical research in question have been selected.

\section{The Training and Employment Exposure Scheme (TEES)}

TEES was an EU-co-funded scheme that took place between 2004 and 2006, aiming to train or retrain 460 unemployed workers in Malta aged 40 and over, who had been seeking employment for over six months. The project was divided into three phases. During the first six months, eligible persons were given training on Core Skills, particularly motivation and self-esteem raising practices. In Phase 2 intensive training was given on skills in demand in the labour market based on a market exercise conducted with employers to obtain vacancies and skills required. During the last phase participants were assigned with an employer for 22 weeks. This work exposure was aimed to pave the way for an offer of permanent employment by the employer at the end of the scheme. ${ }^{32}$ (ETC, 2004b) By the end of the scheme, 251 out of 460 workers found a job through TEES, though this figure rose to 299 given that some found employment through alternative means. ${ }^{33}$

\section{The Quantitative Research Methodology}

A questionnaire was administered to a representative sample of TEES participants. ${ }^{34}$ By means of a Likert 5-point scale, where 1 is the most pessimist rating and 5 is the most optimist rating, participants were asked to rate statements whose content principally explored perceptions on one's status in the labour market, chances of finding stable employment and discouragement. A rating scale was used rather than a ranking scale because a rank is just an order of preferences. On the other hand, ratings scores express the intensity of a preference better than just an order. For the pur-

\footnotetext{
31) Employment and Training Corporation (Malta) $2004 a$.

32) Employment and Training Corporation (Malta) $2004 \mathrm{~b}$.

33) Employment and Training Corporation (Malta) 2007, p.18; Brown 2007, pp.230-1.

34) Brown 2007.
} 
poses of data analysis and its sociological interpretation, ratings lower than 3 were considered as showing feedback that is more on the negative side, whereas ratings equal to or higher than 3 were considered as showing feedback that is more on the positive side.

The questionnaire also elicited socio-demographic data of participants in order to test for any possible correlations between these data and the ratings. Socio-demographic data included gender, place of residents, level of education, marital status, size of household and number of breadwinners in household. In-depth statistical testing revealed that the socio-demographic criteria significantly affecting the ratings given by respondents, were the level of education and the number of breadwinners in the household, as discussed in the next sections.

\section{Level of Education}

Lack of educational qualifications decreases the chances of finding stable employment. ${ }^{35}$ In Malta in particular and the EU in general, the employment rate, by highest level of education is lower for those with lower levels of education and higher for those with higher levels of education. ${ }^{36}$ Older people tend to have relatively lower levels of education. ${ }^{37}$

The majority of respondents in the sample considered in this study have a secondary level of education (60.6\%), followed by those having just primary level of education $(16.3 \%)$, tertiary or post-secondary level $(13.5 \%)$ and basic level (reading and writing) (5.8\%). Some respondents $(3.8 \%)$ did not specify their educational level. ${ }^{38}$ In this last case, it is important to note that some members of the target population and, consequently, some respondents, are registered as illiterate. ${ }^{39}$ Statistical testing reveals that there is a significant difference between respondents of different levels of education, albeit not in a progressive manner. Respondents possessing primary level and tertiary or post-secondary level of education exhibited pessimistic scores (i.e. an average rating score below 3).

In view of these findings, it is suggested that older workers having a primary level of education feel disarmed when confronted by contemporary

\footnotetext{
35) International Labour Organisation 2003, p.12.

36) Eurostat 2008, p.254.

37) Russell and Fahey 2004.

38) Brown 2007, p.116.

39) Brown 2007, p.87.
} 
knowledge-based labour market, whereas older workers having tertiary or post-secondary levels of education are critical of their status in the labour market in view of the loss of status involved in becoming unemployed, and also due to deskilling processes in the labour market, where skills which were valued in the past are no longer required.$^{40}$ Besides, such workers, who educational levels may have been translated in higher wages, may now be disadvantaged against younger, cheaper, more flexible workers as their retraining and relocation to newer sources of employment becomes difficult. $^{41}$ This is not to say that persons with other levels of education do not feel the bite of unemployment, but that pessimism and discouragement characterize the perceptions of those having primary and tertiary or postsecondary levels of education.

\section{Number of Breadwinners}

Income through employment is an essential economic resource for families in urban and industrialized societies, whereby consumption is a key aspect of social life. ${ }^{42}$ In this regard, economic, social and cultural changes have effected the traditional male-breadwinner model, whereby 'being the sole financial supporter for a family has often seemed to be an unattractive, or simply unavailable, option ${ }^{43}$

The majority of respondents considered in this study came from households of one breadwinner, followed by those coming from households where no one earns a salary, those coming from households with 2 breadwinners, 3 breadwinners and 4 breadwinners, respectively (albeit a number of participants did not give such information). ${ }^{44}$ Statistical testing revealed that the number of breadwinners in the household significantly affected mean ratings. The most pessimistic mean ratings (1.25) were given by those having four breadwinners, albeit only a minority of respondents came from such households. ${ }^{45}$

In view of such findings it is hereby suggested that a deeper sense of frustration is felt by older unemployed workers living in such households

\footnotetext{
40) Braverman 1979.

41) Hyman and Streeck 1988.

42) Cheal 2002, p.109.

43) Cheal 2002, p.117.

44) Brown 2007, p.116.

45) Brown 2007, p.116.
} 
as such persons feel that they are unable to give as much economic contribution to the family as other breadwinners in the same household. However, it is suggested that this issue should be subject to further sociological research, also because respondents coming from families having three breadwinners gave positive ratings, similar to those coming from households having two, one and zero breadwinners. Hence, this shows that there is no progressive trend in this regard.

\section{Discouragement}

The 'discouraged worker effect' has been defined as the "decision to refrain from job search as a result of poor chances in the labour market. Discouragement effects can arise from a lack of individual qualifications, from discrimination in the labour market or from a high local level of underemployment." ${ }^{46}$ In Malta, for instance, Lino Briguglio found that this kind of discouraged worker effect existed between 1970 and 1982, in that as employment opportunities decreased, the size of the labour force also decreased. ${ }^{47}$ This suggests that persons who would have formed part of the labour force, opted to move out of it, possibly by not registering as unemployed. This effect was re-confirmed for the period 1983-2004. ${ }^{48}$ This means that even during this period there was indeed a percentage of the labour force who gave up on the job-search completely.

In this regard, discouragement is considered an all or nothing phenomenon, where a person either is in or out of the labour force. Van Ham, Mulder and Hooimeijer identify discrimination and high unemployment rates as causes of the discouraged worker effect, which characterises workers who officially gave up the job-search completely. ${ }^{49}$ Based on the findings

\footnotetext{
46) van Ham, Mulder and Hooimeijer et al. 2001, p.10.

47) Briguglio, L. 1984, pp.539-554. The existence of "the discouraged worker effect" is tested by correlating the unemployment rate (which represents employment opportunities or lack of them, and can be calculated as follows: number of unemployed / size of the labour force $\mathrm{x}$ 100) with the size of the labour force, over a period of time. All other things being constant, if the correlation is negative then one can conclude that "the discouraged worker effect" exists.

48) Caruana 2006, p.21. Kevin Caruana studied female labour market participation in Malta with regard to the Lisbon agenda. His econometric study showed that the total (male and female) unemployment rate had a negative relation with the size of the whole (male and female) labour force in this time period.

49) van Ham, Mulder and Hooimeijer 2001, p.10.
} 
of this empirical study, this paper proposes the following re-articulation of such conceptualisation of discouragement.

The discouraged worker effect is not necessarily the domain of those who gave up the job-search, but, as in the case of TEES participants, and in line with the conceptualisation of Newman, those who are still looking for a job and whose occupational and social status has suffered a blow. This comprises "any slip in occupational status", such as loss of income, place in society, social status or prestige. Experiencing unemployment falls into this scenario. ${ }^{50}$

Thus, the discouraged worker effect can be redefined to incorporate different degrees of discouragement. Indeed, the results of the empirical study in question suggest that discouragement is present amongst ageing workers who are registering as unemployed.In our reading, there are different shades of discouragement and discouragement may also be manifested by those who are still looking for a job, and therefore still members of the labour force.

Factors affecting downward mobility range from market fluctuation to public policy, mergers and post-industrialisation. ${ }^{51}$ The discouraged worker effect can also be associated with social capital. Social capital has been defined as "the set of trust, institutions, social norms, social networks, and organizations that shape the interactions of actors within society and are an asset for the individual and collective production of well-being." 52 Hence, "the individual who is one-to-one with one or more of these social factors at the same time enjoys a degree of stability and social wealth that are more likely to give him/her advantaged status." 53

It follows that one way of reducing discouragement is to enhance social capital among the unemployed, possibly through active unemployment policies, such as training and retraining, improved mobility and improved dissemination of knowledge about vacancies. However, the reduction of discouragement also requires social policy which gives priority to equality and the creation of productive employment. In this regard, the following section concludes this paper by means of a discussion on the significance of this study to labour rights of ageing workers, within an EU context, whereby a case study of a recent work-related issue effecting mostly ageing workers shall be referred to by way of example.

\footnotetext{
50) Newman 1988, p.30.

51) Newman 1988, p.30.

52) Sabatini 2001.

53) Brown 2007, p.226.
} 


\section{Conclusion: Discouragement in an EU Scenario - Neo-Liberalism, Social Struggle and the Need for Productive Employment}

This study shows that members of the $40+$ unemployed labour force in Malta are prone to pessimism and tend to feel disadvantaged in finding employment. Discouragement is high amongst the minority and occasional amongst the vast majority. The study also shows that discouragement is also present amongst those who have not yet given up the job-search and therefore, are still members of the labour force. It follows that discouragement is a process that may start during the job-search. Perceptions tend to be particularly pessimistic amongst those having a primary and tertiary level of education, those coming from families of four breadwinners, and participants of a particular intake of the employment scheme in question. ${ }^{54}$

This reveals the influence of factors related to structure and agency respectively, factors which are not uni-directional and can be therefore explained in terms of multiple identities. ${ }^{55}$ In other words, there are both universal and particular characteristics amongst ageing workers, thus requiring social policy measures which are universal in scope yet particular in relation to specific needs.

Social policies regarding ageing workers, such as the EU training scheme which formed the basis of empirical research for this study, should be seen within the context of EU social policy, which is currently heavily influenced by the Lisbon Agenda, whereby the union is attempting to become the most competitive knowledge-based economy in the world through neo-liberal modernization and related changes to its social model. ${ }^{56}$ Amongst other attempts at hegemonic changes, this involves the replacement of welfare by workfare as a key goal of social policy. ${ }^{57}$

In this regard, social policies of the 'one-size-fits-all' type can help fuel discouragement amongst ageing workers. Such policies, which have been utilized more than once in Malta within an EU-accession context, also include the introduction of retirement schemes for workers deemed surplus in public sector companies. This was carried out in Malta's State postal, telecommunications and shipyards companies prior to their privatization. Such a policy is ironic when one considers that Malta has the lowest employment rate amongst ageing workers in the EU.

\footnotetext{
54) Brown 2007.

55) Barker 2003.

56) Hermann and Hofbauer 2007.

57) Jessop 2008.
} 
The Shipyards case in Malta can be used as a case-study which highlights the struggle between disposing of 'surplus' workers and the prioritization of decent work within intertwining national and EU contexts. ${ }^{58}$ Malta Shipyards was the cradle of Malta's labour movement in the early 20th century and beyond, and was also self-managed by its workers themselves between the 1970s and 1990s. In the past decade the Shipyards witnessed a series of downsizing measures, mainly due to incurred losses and due to the fact that due to Malta's EU membership (2004), direct subsidies have to be phased out by the end of 2008 .

In the second half of 2008, Malta's Nationalist (Christian Democratic) Government, fresh from a third consecutive electoral victory, decided to privatize Malta Shipyards and reduce its already downsized and ageing workforce from 1,800 to 700 by the end of the year through early retirement schemes. This resulted in a series of protests by the workers' representative, the General Workers' Union (GWU), which was supported by the Malta Labour Party, Alternattiva Demokratika - The Green Party, leftist NGOs Zminijietna - Voice of the Left and Moviment Graffitti, as well as by eurosceptic Campaign for National Independence. Malta's highly influential Catholic Church appealed for a just solution to the matter. After a series of discussions between the Government and the Union, agreement was reached whereby retirement schemes were made more generous and whereby Government committed itself to negotiate a work guarantee with the new prospective owner of the Shipyards for a number of years. Should there still be a number of unwanted workers, the Government and the General Workers' Union agreed to form a joint commission to seek alternative employment for such workers. At the same time, however, it remains to be seen whether such workers can be made redundant by the new employer, as EU legislation does not permit this in the case of a transfer of business. Indeed, the European Commissioner for Employment, Social Affairs and Equal Opportunities has been asked to investigate this matter by Malta's Green Party.

The plot has become further complicated due to the intervention of the EU Commissioner for Competiveness, who poured cold water on the agreement reached by the Maltese Government and the GWU, stating that the government's intention to write off about $€ 100$ million in debts before selling Malta Shipyards violated EU rules. The EU Commission has put

58) The Malta Shipyards example is not dissimilar from other current cases in an EU context, such as Alitalia (Italy) and Gdansk Shipyards (Poland). 
pressure on the Maltese Government to declare Malta Shipyards bankrupt and liquidate the company before continuing the privatization process. This has resulted in a hefty increase of Shipyard workers who applied for retirement schemes. Indeed, by the end of the expiry date for the retirement schemes offer, only 56 workers opted to remain with the company. ${ }^{59}$

The Malta Shipyards case shows that, through overdetermining factors such as social conflict and structural constraints, the identity of its (mostly) ageing workers is the subject of conflicting views, including that of 'surplus', that of a group that requires social protection, and that of a social group that requires employment by right.

Whilst the declared position of the Maltese Government was transformed in a couple of weeks, mainly due to the struggle of the workers, their representatives and their allies, on the other hand, the intervention of the EU Commissioner for Competitiveness, has shown that employment issues have in many instances taken a global dimension. This calls for global activism, which is already taken place in certain areas, such as Green politics. ${ }^{60}$ In the particular context of employment, it is "crucial that trade unions... work together with social movements... in order to stem the neoliberal Anglo-American model and re-establish a European social model of capitalism. This would provide a combination of traditional organizational structures with developments from below, creating a very powerful movement in size and numbers for the challenge of neoliberal restructuring at the national, European and global level." 61

Hence, in this day and age of neo-liberal policies based on privatization, downsizing and competitiveness; of postmodern multiple identities based on particular life-styles, experiences and tastes, the universal quest for equality remains a rallying cry for the subaltern. Productive work remains a key goal not only for ageing workers in particular, but also for social and economic development in general. Such a universal goal requires mass representation of trade unions, which, in turn, require the construction of alliances to widen their appeal. In this regard, training schemes become one tool amongst many so that workers may be in more decent work, and

\footnotetext{
59) The Shipyards issue has been reported extensively by the Maltese press. Examples include the General Workers' Union daily L-Orizzont (in Maltese), and national independent newspapers The Times, Malta Today, and The Malta Independent (in English - Malta is a bilingual country, whereby both Maltese and English are national languages).

60) Briguglio, M. 2003.

61) Bieler 2003.
} 
not an end-of-pipe solution for workers who are deemed 'surplus' within a neo-liberal context.

If the battle against discouragement is to be given priority, policies which do away with 'surplus' workers should be replaced by inclusive and active social policy which focuses on the need for such persons to be full participants in social life, not least in the world of work. In this regard, decent work should be a key goal for social policy. As the International Labour Organization puts it, "decent work sums up the aspirations of people in their working lives. It involves opportunities for work that is productive and delivers a fair income, security in the workplace and social protection for families, better prospects for personal development and social integration, freedom for people to express their concerns, organize and participate in the decisions that affect their lives and equality of opportunity and treatment for all women and men". ${ }^{2}$

\section{References}

Alcock, Pete and Erskine, Angus 2003, 'Divisions, Differences and Exclusion', in Pete Alcock, Angus Erskine, and Margaret May (eds), The Student's Companion to Social Policy, Oxford: Blackwell Publishers.

Barker, Chis 2003, Cultural Studies: Theory and Practice. London: SAGE Publications.

Bieler, Andreas 2003, 'What Future Union? The Struggle for a Social Europe', Queen's Papers on Europeanisation, http://www.qub.ac.uk/schools/SchoolofPoliticsInternationalStudiesandPhilosophy/FileStore/EuropeanisationFiles/Filetoupload,38413,en. pdf (16 September 2008).

Braverman, Harry 1979, Labour and Monopoly Capital: The Degradation of Work in the Twentieth Century, Trivandrum: Social Scientist Press.

Briguglio, Lino 1984, 'The Specification and Estimation of a Disequilibrium Labour Market Model', Applied Economics. 16, 4: 539-54.

Briguglio, Michael 2003, 'Global Dominance / Global Resistance', in Carmel Vassallo and Clare Thake Vassallo, (eds), The Communist Manifesto - Karl Marx's Legacy to Humanity, pp. 23-39, Malta: Malta University Press.

Brown, Maria 2007. Life Begins at Forty: A Sociological Study of Unemployment of Persons aged Forty years and over in Malta. Malta: Unpublished dissertation, University of Malta.

Caruana, Kevin 2006. 'Female Labour Market participation in Malta: A Lisbon Agenda Perspective', Bank of Valletta Review 33: 15-32.

Cheal, David 2002, Sociology of Family Life. Hampshire: Palgrave.

Duncan, Colin 2003, 'Assessing anti-ageism routes to older workers re-engagement', Work, Employment and Society. 17, 1: 101-120.

62) http://www.ilo.org/global/Themes/Decentwork/lang--en/index.htm. 
Employment and Training Corporation 2004a, 'Work Start Scheme', http://www.etc.gov. $\mathrm{mt} /$ site/page. aspx?pageid=2109 (1 November 2005).

Employment and Training Corporation 2004b, 'Employment Training Placement Scheme', http://www.etc.gov.mt/site/page.aspx?pageid=2017 (1 November 2005).

Employment and Training Corporation. 2007, TEES Achievements and Statistics, Malta: Employment and Training Corporation.

EUROPA 2000, 'Presidency Conclusions. Lisbon European Council. 23 and 24 March 2000', http://www.consilium.europa.eu/ueDocs/cms_Data/docs/pressData/en/ec/00100r1.en0.htm (1 November 2005).

European Commission 2004a, 'Employment in Europe Report 2004 - Executive Summary', http://ec.europa.eu/research/future/pdf/comm_sec_2005_0430_1_en.pdf(1 November 2005).

European Commission 2004b, 'Communication from the Commission. Strengthening the implementation of the European Employment Strategy', http://europa.eu.int/eur-lex/ en/com/pdf/2004/com2004_0239en01.pdf (1 November 2005).

Eurostat 2008, Europe in figures - Eurostat yearbook 2008. Luxembourg: Office for Official Publications of the European Communities.

Formosa, Marvin 2000. 'Exposing Ageism'. University of Malta, http://www.um.edu.mt/ pub/formosam3.html (6 March 2006).

Giddens, Anthony 1998, The Third Way: The Renewal of Social Democracy, Cambridge: Polity Press.

Giddens, Anthony 2007, Europe in the Global Age, Cambridge: Polity Press

Hermann, Christoph and Hofbauer, Ines 2007, 'The European social model: Between competitive modernisation and neoliberal resistance', Capital and Class, 93: 125-140.

Harvey, David 1990, The Condition of Postmodernity: An Enquiry into the Origins of Cultural Change, Oxford: Blackwell.

Hyman, Richard and Streeck, Wolfgang (eds.) 1988: New Technology and Industrial Relations, Oxford: Blackwell.

International Labour Organisation 2003, 'International Labour Conference. 2003. Report IV (1) Learning and training for Work in Knowledge Society', http://www.ilo.org/ public/english/employment/skills/download/report4.pdf (8 November 2006).

Jessop, Bob. (2008): State Power. Cambridge: Polity Press.

Loretto, Wendy, Vickerstaff, Sarah, and White, Phil 2005, 'Older workers and options for flexible work', Equal Opportunities Commission, Working Paper Series, 31, Manchester: Equal Opportunities Commission.

Marx, Karl 1971, Capital. Vol. 1. Moscow: Progress Publishers.

Ministry of Education 2004, National Action Plan for Employment Malta 2004, Malta: Ministry of Education.

National Statistics Office 2008,'Registered Unemployed: July 2008: http://www.nso.gov. $\mathrm{mt} /$ statdoc/document_file.aspx?id=2306 (15 September 2008).

Newman, Katherine S. 1988, Falling from grace: The experience of downward mobility in the American middle class. New York: The Free Press.

Platman, Kerry and Tinker, Anthea 1998, Getting on in the B.B.C.: a case study of older workers', Ageing and Society, 18, 5: 513-535.

Rizzo, Saviour 2004, 'The Family', in George Cassar \& JosAnn Cutajar (eds) Sociological Aspects of the Maltese Islands, pp. 14-32. Malta: Indigo Books. 
Russell, Helen and Fahey, Tony 2004, 'Ageing and labour market participation', http:// www.equality.ie/index.asp?locID=105\&docID=82. (16 September 2008).

Sabatini Fabio 2001, 'What is Social Capital?', The Social Capital Gateway, http://www. socialcapitalgateway.org/NV-eng-labour.htm 13 December 2006.

Tabone Carmel 1995, Maltese Families in Transition. Malta: Ministry for Social Policy.

van Ham, Maarten, Mulder, Clara H and Hooimeijer, Pieter 2001, 'Local Underemployment and the Discouraged Worker Effect', Urban Studies, 38, 10: 1733-1751.

\section{Newspapers}

L-Orizzont http://www.l-orizzont.com/

The Times http://www.timesofmalta.com

Malta Today http://www.maltatoday.com.mt

The Malta Independent http://www.independent.com.mt/ 